\title{
A Gigante Brasil Industrial: herança e modernidade no Vale Paraíba Fluminense; a Fábrica Paracambi na segunda metade do século XIX.
}

The Brazilian Industrial Giant: heritage and modernity in Vale Paraíba Fluminense

La Gigante Brasil Industrial: herencia y modernidad en el Valle Paraíba Fluminense

La géante Brasil Industrial: héritage et modernité dans la Valée Paraiba Fluminense; l'usine de Paracambi dans la seconde moitié du 19ème siècle.

\section{Cristiane Silva Furtado}

\section{OpenEdition}

Journals

Edição electrónica

URL: http://journals.openedition.org/espacoeconomia/3175

DOI: 10.4000/espacoeconomia.3175

ISSN: 2317-7837

Editora

Núcleo de Pesquisa Espaço \& Economia

Refêrencia eletrónica

Cristiane Silva Furtado, « A Gigante Brasil Industrial: herança e modernidade no Vale Paraíba

Fluminense; a Fábrica Paracambi na segunda metade do século XIX. », Espaço e Economia [Online],

12 | 2018, posto online no dia 14 julho 2018, consultado o 30 abril 2019. URL : http://

journals.openedition.org/espacoeconomia/3175; DOI : 10.4000/espacoeconomia.3175

Este documento foi criado de forma automática no dia 30 Abril 2019.

(C) NUPEE 


\title{
A Gigante Brasil Industrial: herança e modernidade no Vale Paraíba Fluminense; a Fábrica Paracambi na segunda metade do século XIX.
}

\author{
The Brazilian Industrial Giant: heritage and modernity in Vale Paraíba \\ Fluminense \\ La Gigante Brasil Industrial: herencia y modernidad en el Valle Paraíba \\ Fluminense \\ La géante Brasil Industrial: héritage et modernité dans la Valée Paraiba \\ Fluminense; l'usine de Paracambi dans la seconde moitié du 19ème siècle.
}

\section{Cristiane Silva Furtado}

\begin{abstract}
Desprendeu-se involuntariamente dos lábios um brado de admiração, ao avistarmos, vencida uma ligeira volta da estrada, pouco além da estação de Macacos, no fundo de uma esplanada semi-circular, a fachada simples e ao mesmo tempo imponente do edifício, flanqueada por dois bem traçados torreões, a que sobrepuja, no centro, um terceiro, semelhante a essas torres de menagem dos velhos castelos europeus.

Destaca-se vivamente sobre a cinzenta base de pedra rústica, e dentre o verde escuro das árvores, o vermelho dos tijolos de que é construído o palácio, pois que o é - do trabalho e da indústria. (A REFORMA, 1874.p.2)
\end{abstract}

1 O brado de admiração solto pelos visitantes ao avistarem o imponente prédio de uma fábrica, no pequeno povoado de Ribeirão dos Macacos, é um misto de incredulidade e expectativa diante do maior projeto fabril têxtil realizado no Império do Brasil até aquele momento: a Companhia Têxtil Brasil Industrial. Um empreendimento "novo", "ousado", "grandioso", como colocado no Primeiro relatório aos Acionistas da Companhia e nas notícias de jornais da corte, um verdadeiro "palácio do trabalho e da indústria" que nascia em terras brasileiras em 1871. Diante de tão "ousado" projeto todos os que a visitavam tinham palavras de admiração - "magnífico", "grandioso" - e expectativas de 
prosperidade diante do modelo que ela significava para indústria brasileira nascente. (COMPANHIA BRASIL INDUSTRIAL, 1874.p.2)

2 A importância dessa iniciativa pode ser compreendida se atentarmos para a história da implantação da Fábrica. A Companhia Brasil Industrial iniciou o projeto de construção de uma nova fábrica de tecidos na Província do Rio de Janeiro na segunda metade do século XIX, após a construção da estrada de Ferro Pedro II. Localizada na atual Cidade de Paracambi, teve sua construção iniciada em 7 de setembro de 1870 e foi inaugurada no dia 6 de dezembro de 1871(COMPANHIA BRASIL INDUSTRIAL, 1874.p.8) Construída nos pés da Serra do Mar, na região denominada Vale do Paraíba, em terras desmembradas da antiga fazenda do Ribeirão dos Macacos, a fábrica constituiu um empreendimento, segundo os relatórios da própria Companhia, considerado "grandioso" para sua época (O MEQUETREFE, 1875.p.2). De fato, contando inicialmente com 450 teares, 24.000 fusos, uma força motriz de $350 \mathrm{hp} \mathrm{e} \mathrm{com} \mathrm{capital} \mathrm{inicial} \mathrm{de} 1000$ contos, a Brasil Industrial era, segundo seus diretores, o maior projeto da indústria têxtil do Império brasileiro (COMPANHIA BRASIL INDUSTRIAL, 1874.p.8).

Inserida em um contexto nacional de experiência industrial incipiente - marcado por investimentos ainda tímidos nas empresas industriais nascentes, no qual o projeto de industrialização brasileira lutava por algum espaço junto à iniciativa governamental em um país marcado pela agricultura exportadora (COMPANHIA BRASIL INDUSTRIAL, 1874.) ${ }^{1}$ - não parece exagero dos contemporâneos a ênfase na grandiosidade do projeto, afirmada pelos acionistas da Companhia em seu primeiro relatório. Entre 1860 e 1880 o país possuía 45 fábricas, a maioria de pequeno porte, contando em média com 55 teares e 67,5 h.p., unidade que representa a força hidráulica utilizada para mover o maquinismo. $\mathrm{Na}$ comparação, evidencia-se a pretensão grandiosa da nova fábrica da Brasil Industrial, que abre suas portas equipada com 450 teares, e 350h.p. de força motriz (COMPANHIA BRASIL INDUSTRIAL, 1874.p.8).

Por ter se constituído, assim, como a maior fábrica de tecidos do Brasil até o início do século XX, a Companhia Brasil Industrial nos permite acompanhar diversas questões referentes ao início e ao desenrolar do processo de industrialização no Brasil do período. A primeira dessas questões diz respeito à própria relação entre o novo empreendimento $\mathrm{e}$ a vocação agrícola da região (e do país) em que foi instalada (STEIN, 1979). Não foi à toa que a escolha do local para construção da grande fábrica de tecidos foi a fazenda Ribeirão dos Macacos, aos pés do Vale do Paraíba, lugar cuja origem e tradição remetem aos grandes fazendeiros de café. Se atentarmos para as justificativas dos acionistas nos primeiros relatórios da Companhia, a escolha do lugar para a construção da fábrica deveria respeitar dois critérios principais: a existência de água em abundância, para mover os teares, e a possibilidade de transporte fácil e rápido, para viabilizar a construção da fábrica e o posterior escoamento de sua produção. A fazenda do Ribeirão dos Macacos atendia "vantajosamente" ao primeiro critério, uma vez que possuía não somente mananciais de água, como "altura pouco comum das águas aproveitáveis para moverem o maquinismo" (COMPANHIA BRASIL INDUSTRIAL,1874.p.8). É o segundo desses critérios, no entanto, que aparece como vital nas falas dos acionistas. Situada à beira dos ramais da Estrada de Ferro Dom Pedro II, o empreendimento poderia contar com os "favores" do governo para permitir o transporte gratuito para a fábrica pela ferrovia (COMPANHIA BRASIL INDUSTRIAL,1874.p.8).

5 O investimento feito pelo Império brasileiro para a modernização das estruturas no Vale do Paraíba parece deixar claros os motivos da escolha do lugar em que seria construída a 
Brasil Industrial. Se outras regiões do Estado poderiam contar com a mesma abundância de águas, a singularidade dessa localidade estava nas boas condições de estrutura que ela já apresentava naquele momento. De fato, essas "vantagens", como colocam os acionistas da Brasil Industrial (COMPANHIA BRASIL INDUSTRIAL, 1874.p.17), estão intimamente ligadas à sua importância no cenário econômico. 0 que faz da implementação da fábrica na região um empreendimento estratégico que procura se fixar no lugar onde está concentrado o projeto nacional imperial para o desenvolvimento e modernização da economia brasileira. É no rastro do projeto nacional, que conta com o apoio da Coroa, que os pioneiros da Brasil Industrial encontram as bases para estabelecer o que pretende ser o modelo industrial brasileiro.

6 Stanley Stein, autor de obras importantes sobre a região do Vale do Paraíba e posteriormente sobre a industrialização brasileira, chama atenção, em "Origens e Evolução da Indústria Têxtil no Brasil, 1850/1950", para o fato de que o desenvolvimento da indústria brasileira no século XIX se deu à sombra da agricultura e do comércio, pilares que ainda sustentavam a economia brasileira (STEIN, 1979. p.20). Em outro livro, "Grandeza e decadência do café no vale do Paraíba: com referência especial ao município de Vassouras", Stein afirma que, a construção das ferrovias no Brasil obedecera à necessidade do escoamento agrícola, sobretudo do café, não tendo sido construídos trilhos secundários para o fortalecimento do comércio interno (STEIN, 1961.p.353). Tal afirmação sugere que o surgimento da indústria no Brasil se deu sob o espectro de um projeto econômico que teve na agricultura seu mais forte braço. Dessa forma, é significativo que a criação de uma indústria modelo como a Brasil Industrial se faça propositalmente na trilha da força agrícola da principal região cafeeira e escravocrata do Brasil nesse período. Embora estivesse há uma hora e meia, por linha férrea, da capital, os serviços oferecidos àquela região possibilitavam a implementação, no Vale do Paraíba, de uma indústria daquele porte. A constituição do capital industrial brasileiro nasceu, assim, ao lado do latifúndio agrícola, amplamente amparado pelo investimento em modernização das comunicações e transporte, feito pelo projeto do governo brasileiro da época.

7 Por mais que o projeto da nova fábrica apontasse para o futuro, para um ideal de progresso ainda por fazer-se, foi nas brechas do modelo de produção predominantemente agrícola que conseguira se instalar. A especificidade desse projeto, então, assentava-se nessa relação de complementaridade entre elementos novos e tradicionais; na conjugação de práticas ligadas ao modelo agrário e ao modelo de industrialização importado da Inglaterra. As dificuldades enfrentadas demarcavam o lugar desse empreendimento no projeto nacional do Império brasileiro: o futuro.

8 A Companhia Brasil Industrial foi idealizada e construída por empresários que faziam parte de uma elite imperial ligada aos negócios do café. Esse novo empreendimento reivindicou novas formas de relação de trabalho, que foram moldadas, contudo, a partir de velhas práticas de dominação senhorial. Cristiane Maria Magalhães, ao analisar a fábrica de tecidos Companhia União Itabirana, ressalta a ambivalência dessa nova realidade industrial, que interligava um conjunto de práticas notadamente patriarcais a um modelo de produção "moderno". Conforme a autora, a relação entre empresários e trabalhadores foi se moldando no cotidiano, na própria experiência do contexto fabril.

Surgia, com a implementação das fábricas de tecidos, uma nova forma de organização econômica, distinta da anterior de produção, doméstica dos panos de minas. Com investimentos de capital proveniente de atividades econômicas diversas, organizadas segundo parâmetro da racionalidade técnica, as indústrias 
têxteis mineiras também requeriam um novo tipo de empreendedor e de trabalhador. Uns e outros se fariam no processo de funcionamento das empresas têxteis. Em outras palavras, foi no próprio processo de industrialização que esses homens aprenderam a gerir os seus negócios e transformaram-se em empresários industriais, sem contudo, abrirem mão da carga cultural que os ligava ao mundo das relações patriarcais. (MAGALHÃES, 2008. p.221)

A "carga cultural que os ligava ao mundo das relações patriarcais", que se refere Cristiane Magalhães, formou o campo de experiência e referenciais por onde esses homens se movimentavam. A partir dessa carga cultural, os empresários brasileiros moldaram e implementaram as relações de trabalho e gerência do espaço da indústria nascente em continuidade às relações paternalistas senhoriais. É possível afirmar, então, que os homens ligados à gerência da Brasil Industrial no Vale Paraíba aprenderam a conduzir seus negócios e transformaram-se em empresários industriais a partir do arcabouço cultural que os ligava ao mundo das relações patriarcais.

Nessa perspectiva, não parece surpreendente a continuidade da lógica patriarcal dentre os patrocinadores da nova empresa se atentarmos para sua composição social. Os investidores dos projetos fabris no Brasil tinham o perfil social semelhante àqueles dos grandes proprietários de terras do Vale do Paraíba. Entre os membros da diretoria da Companhia estavam o Sr. Joaquim de Lima e Silva Sobrinho, depois Visconde do Tocantins, que era membro do parlamento, o Sr. Barão de S. Francisco Filho e o comendador João Batista Vianna Drummond (COMPANHIA BRASIL INDUSTRIAL, 1874.) que, além de comendador, era amigo de Dom Pedro II e foi o responsável pela criação do jogo do bicho (HERSHMANN E LERNER, 1993). Todos eram, assim, membros proeminentes da elite imperial. $O$ investimento desses senhores nessa indústria nascente demonstra sua inserção no projeto nacional do Império, que percebe na industrialização a possibilidade de modernização de sua economia.

Desse modo, longe de antagonismos e dicotomias que se inscrevem na lógica do rural e urbano, o primeiro grande projeto da indústria brasileira se formou a partir de signos comuns com a economia rural, numa relação marcada entre similaridade e diferença, continuidade e ruptura, evidenciadas no processo de industrialização brasileira, e percebidas nas especificidades da implementação da maior fábrica têxtil do Brasil durante o séc. XIX.

12 A formação da Brasil Industrial se inseriu, portanto, em movimento ligado à lógica de desenvolvimento do projeto nacional do Império, que se localizava na simultaneidade e complementaridade da atividade agrícola, visando à modernização da economia brasileira. Não são à toa os esforços e investimentos da Coroa numa estrutura que permitisse a modernização econômica brasileira, como a implementação de ferrovias, melhorias urbanas e serviços de comunicação. 0 projeto fabril têxtil da Companhia Brasil Industrial estava englobado no ideal de progresso e modernização, que compreendia a necessidade de transformação da economia brasileira. Construída sob os moldes industriais do Velho Mundo, a fábrica modificou a paisagem, estruturou e desenhou o lugar, instalando um verdadeiro complexo composto por fábrica e vila operária.

o momento de inauguração oficial com a presença do Imperador demonstra o sucesso do empreendimento $\mathrm{O}$ sucesso da festa, a boa impressão dos presentes e, sem dúvida, a ida de D. Pedro II à fábrica Brasil Industrial demarcam o lugar da novidade e expectativa sobre o projeto. A presença do Imperador do Brasil em Macacos afirma simbolicamente o sucesso 
do empreendimento e a inserção da indústria no projeto imperial de modernização da economia brasileira, lado a lado com a agricultura cafeeira.

Ainda que marcada pela novidade e modernidade o projeto singular da Companhia Brasil Industrial foi desenvolvido em meio a um mundo rural que configura seu espaço e relaçães. Entre modernidade e tradição aconteceu a adaptação do projeto baseado nas fábricas com vila operária das cidades inglesas. Se o projeto pretendido pela Brasil Industrial estava centrado nas fábricas de origem inglesa, com a estrutura da vila operária, seu desenvolvimento requereu a adaptação para a realidade do país e da região em que viria a se desenvolver. $O$ processo dessa adaptação pode ser percebido no desenrolar da formação do povoado e da mão de obra da fábrica.

Até o ano de 1888 muitos dos antigos barões de café dessa região defendiam a utilização da mão de obra escrava na lavoura, mesmo quando o processo de abolição se mostrava irreversível. O testemunho de Luis Couty, médico francês que trabalhou no Museu Nacional do Rio de Janeiro, citado por Stanley Stein, demonstra claramente essa realidade. Ao censurar os fazendeiros da região por não tentarem substituir o trabalho escravo pelo trabalho livre, ele teria ouvido de um antigo fazendeiro, no início de 1880 , a seguinte afirmação: "Meus filhos, que herdarão minhas propriedades, farão como quiserem; porém, quanto a mim, não posso habituar-me a trabalhadores que não sejam escravos" (STEIN, 1961. p.275). Tais palavras levaram Luis Couty a concluir que, para os antigos fazendeiros da região, "o negócio complexo de possuir uma fazenda e produzir café era inseparável da escravatura, sem a qual a palavra fazendeiro, nada significava" (STEIN, 1961.p.275). Se para os senhores escravidão e produção agrícola caminhavam lado a lado, não seria diferente a postura dos próprios escravos - o que levava muito daqueles que escapavam do regime do cativeiro a buscar novas alternativas de sobrevivência. Stanley Stein afirma que a busca mesmo por atividades dissociadas do meio agrícola seria comum entre os ex-escravos da região, que buscavam estabelecer uma separação legal dos seus antigos senhores e suas fazendas. Essa lógica poderia ser verificada tanto durante $o$ regime escravocrata, por parte de ex-escravos que conseguiam por diversos meios suas alforrias, quanto no momento pós-abolição (STEIN, 1961.p.311). Outra questão colocada pelo autor, que pode elucidar as dinâmicas experimentadas pelos libertos da região, e que estavam na expectativa da implementação desse novo projeto de trabalho, é a de que principalmente as mulheres, quando na condição de libertas, abandonavam as fazendas e a vida agrícola (STEIN, 1961.p.315). Desse modo, era clara a atração exercida entre os trabalhadores da região, escravizados ou não, pelo novo empreendimento fabril. Entretanto, se era esperada uma separação legal dos senhores, esses homens e mulheres, livres ou alforriados, ao procurarem outra atividade que não fosse agrícola, se deparavam com semelhanças e continuidades entre esses mundos que compartilhavam análogas práticas de dominação efetivas e simbólicas. Stein mostra como foram as acomodações dos primeiros operários da fábrica:
A fábrica têxtil de algodão Brasil Industrial uma das maiores do país no século XIX, cresceu em meio a uma grande plantação; os empresários ocuparam a antiga casa- grande de dois andares ("recentemente convertida em hospedaria para cem meninos operários que empregamos"), um depósito e a senzala dos escravos ao lado do forno ("ocupado agora pelo forno, a ferraria e trabalhadores residentes"). (STEIN, 1979.p.55).

16 A citação mostra as relações entre a antiga estrutura da fazenda e as que se formavam na fábrica. O fato dos empresários terem ocupado a casa-grande, já os coloca na mesma posição simbólica de poder dos antigos fazendeiros senhores de escravos. Após uma 
reforma converteu-se na hospedaria para abrigar os cem meninos operários, o que nos parece indicar uma adaptação da estrutura fabril. Os trabalhadores residentes, entretanto, ocupavam o lugar da senzala, antes ocupada somente por escravos, agora também por trabalhadores livres.

Um contraponto interessante para se perceber o movimento de acomodação desses primeiros operários da Brasil Industrial pode ser visto por meio de uma observação feita por Paulo Fernandes Keller, que aparece como o pioneiro no estudo das fábricas da região. Ao tratar da ocupação da vila operária construída ao lado da fábrica, ele ressalta que muitas vezes as famílias dos novos operários fabris não eram compostas por seus patriarcas, que permaneciam presos à lavoura. Os que iam para a fábrica eram os filhos, irmãos e noras, que formavam essa nova força de trabalho.

Solicitar casa da vila operária era uma tarefa do irmão ou irmã mais velhos; nem sempre era o pai de família o solicitante. Nestes casos, o pai havia ficado no trabalho da lavoura, cuidando dos pertences da família, ou, devido à idade preso ao seu modo de vida. (KELLER, 1997.)

18 Tal relato sugere uma lógica de moradia que estabelece uma relação de continuidade entre escravidão e a nova forma de trabalho que se estabelecia, marcando um cruzamento de poder hierárquico entre a antiga estrutura da fazenda e nova forma fabril em formação. Essas informações nos dão indícios de que se formou na região uma nova cultura de trabalho no pós-abolição, a partir da experiência de trabalhadores que, embora mais jovens do que os ex-escravos ou mesmo homens livres mais velhos ligados ao mundo senhorial, haviam se formado por dentro dessa lógica, partindo dela para constituir seus novos laços de sociabilidade e identidade (STEIN, 1961.p.311)².

19 Não é de se estranhar que o recrutamento dessa mão de obra não especializada fosse muitas vezes feito em juizados de menores, Casas de Caridade e orfanatos. Ainda em 1874, na inauguração da fábrica o jornal A Reforma referia-se às boas intenções dos seus diretores:

Soubemos com prazer, que o ilustrado Sr. Conselheiro Zacharias prometeu auxilialos oportunamente em tão nobre intuito, confiando-lhes alguns menores dependentes da Santa Casa da Misericórdia.

Fora para desejar que as autoridades seguissem tão belo exemplo.

Os juízes de órfãos, que são obrigados a dar de soldada os meninos desvalidos, podiam aproveitar com vantagem as facilidades que oferece-lhes a Brasil Industrial para o desempenho de tão benéfica atribuição.

Que melhor destino pode ter esses desamparados da sorte? Além de vestuário, sustento e educação, adquirirão ali um meio de vida, que afastá-los-á dos maus tratos, da necessidade e da miséria, e irão desde logo constituindo aos poucos um pecúlio, que servirá para se estabelecerem, atingida a maioridade.

Aplica-los à fabricação de algodão, trabalho leve e isento de perigos, é sem dúvida preferível a encerrá-los nas fábricas de cigarros, onde vivem no meio de uma atmosfera viciada pelas exalações de fumo e sensivelmente contraem o vício do seu uso. (A REFORMA, 1874. p.2)

Os menores confiados à Brasil industrial não só teriam um futuro longe da miséria, como também seriam o futuro de um Brasil moderno, industrial, com sua mão de obra aplicada ao trabalho e crescimento industrial. A aplicação dos menores nas atividades industriais parece uma forma de moldar o trabalho fabril desde cedo.

21 Entretanto, o entusiasmo quanto ao futuro dos pequenos miseráveis nos choca nos deparamos com o único relatório médico datado de 1891, onde se percebe que a maior parte dos casos de acidente de trabalho seguidos de desarticulação (amputação) de 
membros se referia a meninos e meninas entre 7 e 12 anos de idade, nesta época, já quase todos filhos de operários residentes da Brasil Industrial (COMPANHIA BRASIL INDUSTRIAL, 1891). Os números aterradores e as descrições dos acidentes de trabalho colocam as crianças e mulheres como as principais vítimas. A utilização da mão de obra de mulheres e dos menores na fábrica, longe de representar a preocupação filantrópica desses industriais, os liga a um regime bastante semelhante à escravidão, com controle rígido do tempo de trabalho e com imensos riscos físicos aos trabalhadores, como mostra o relatório médico de 1891.

22 A implementação da Fábrica da Companhia Brasil Industrial ${ }^{3}$ representa, assim, uma novidade marcante não só para a lógica de produção de uma região até então inserida somente na antiga estrutura agrário-exportadora primordialmente escravocrata, mas também para o universo dos trabalhadores locais, livres ou escravos. Experimentando cotidianamente o progressivo esgarçamento da ideologia de domínio que por décadas havia sustentado sua sujeição, à qual se ligava a decadência de seus senhores e a conquista de novos espaços de liberdade (CHALHOUB,1990) ${ }^{4}$, os escravos da região teriam na fábrica uma clara alternativa de sobrevivência. Nela teriam, no entanto, que conviver com os trabalhadores livres, nacionais e estrangeiros, atraídos pela Direção da Fábrica para viabilizar a produção. Nesse contexto, os limites entre o trabalho livre e o trabalho escravo já se configuravam de forma mais tênue - pois, sob a lógica industrial da fábrica, em sua tentativa de sistema fabril disciplinar, tanto uns como outros se transformavam em simples força de trabalho.

A mistura entre o trabalho escravo e o trabalho livre acompanhou o espaço fabril da Brasil Industrial. Diante da adaptação das estruturas e formas de trabalho de origem rural estão as permanências das relações patriarcais que marcaram o mundo do trabalho escravo até a abolição. Exemplo disso é um acontecimento de 1876, quando é citado no Terceiro Relatório aos Acionistas o número de empregados "de 251, sendo: homens 203, e mulheres 48. Os menores compreendidos nestes são 58 meninos e 13 meninas" (COMPANHIA BRASIL INDUSTRIAL, 1876. p.9.). Curiosa, ainda é a citação feita nesse terceiro relatório da Companhia, que aponta para um cessar das dificuldades de aquisição de operários, e ainda que, "a marcha do estabelecimento tem deixado de ser perturbada, por qualquer incidente ou conflito por eles suscitado, graças ao respeito e estima que o atual administrador tem sabido angariar" (COMPANHIA BRASIL INDUSTRIAL, 1876.p.9). A informação contida nesse relatório mostra que, em algum momento no decorrer desses dois anos do estabelecimento da Companhia Brasil Industrial, houve algum conflito entre os trabalhadores e que, aparentemente devido a mudança de administração, conseguiu ser apaziguado pelo "respeito e estima" que o novo administrador pareceu construir com os operários. A lógica de saber angariar a estima do operariado, descrita pelo novo gerente, parece se inserir nos moldes da relação paternalista, que pretende a gratidão do subalterno como forma de controle. O novo administrador em questão é o senhor Eduardo dos Guimarães, que havia ocupado o lugar desde 13 de julho de 1875 e, segundo o parecer da Companhia "tem até o presente desempenhado os deveres do seu largo" (COMPANHIA BRASIL INDUSTRIAL, 1876. p.11). A solução do incidente pela substituição do gerente que angariava respeito e estima demarca o lugar de continuidade das relações do século XIX.

No Quinto Relatório de 1878, junto com a implementação da escola noturna para os aprendizes, que caracteriza um momento de enquadramento dos menores às necessidades da Companhia, outro movimento pode ser observado: a abertura de um 
espaço de convivência que não passa pelas necessidades da fábrica de enquadramento e preparação da mão de obra.

o número dos operários que trabalharam no período de que se trata foi de 343 , sendo 146 homens, 31 mulheres, 132 meninos, e 34 meninas, estando compreendidos no número dos meninos 72 aprendizes, que fazem progresso na aula noturna de instrução primaria, alguns dos quais pertencem a uma banda de música ali organizada pelos operários. Este benefício, que a Companhia faz aqueles jovens, preparando-os para serem cidadãos uteis ao país, dá-nos o direito de esperar, que os poderes públicos prestem razoável proteção a este nosso grande cometimento industrial, sem igual segundo afirmam, nos países mais adiantados nessa espécie de industrial. (COMPANHIA BRASIL INDUSTRIAL. 1878. p.8)

Duas coisas parecem de extrema importância nessa passagem: a primeira diz respeito à atenção que a Companhia está dispondo à preparação de aprendizes, com a iniciativa da fábrica da construção de uma escola noturna. A passagem ainda aponta para a tentativa de reconhecimento do governo em prol dessa iniciativa, utilizando o mesmo discurso de benevolência e prosperidade de outrora. A segunda, que quase passa despercebida no relatório, diz respeito ao movimento feito pelos próprios funcionários para organizar uma banda de música, da qual, alguns desses meninos aprendizes, frequentadores da escola noturna da fábrica, também fazem parte.

o fato de alguns funcionários terem organizado uma banda de música por iniciativa própria parece ser significativo, e é o primeiro empreendimento associativo reconhecido pela diretoria, no espaço até então destinado à produção e reprodução daquele mundo do trabalho. Organizada por iniciativa dos trabalhadores e consentida pela direção, a banda de música não é mais citada pelos relatórios até que, de forma curiosa, reaparece quase vinte anos depois da primeira citação, no relatório da Companhia datado de 1895, em que a mesma banda é citada como sendo reorganizada pela diretoria da Fábrica. Num tópico desse relatório intitulado, "Escola Prática de Música", encontramos o seguinte:

Comprovada pela experiência a necessidade de proporcionar-se o ensino da música aos operários do estabelecimento que mostram gosto por essa arte, foi ali reorganizada uma banda instrumental que atualmente conta com 25 figuras.

A aplicação e gosto desse pessoal, auxiliado pela diretoria, levou a esta dar-lhes um mestre que ultimamente foi substituído por pessoa de reconhecida idoneidade, tem consideravelmente manifestado o acerto de semelhante reorganização, que com pequeno dispêndio para a Companhia, proporciona a todo seu pessoal, utilíssima e agradável recreação, pois é força confessar que a referida banda musical tem feito grandes progressos. (COMPANHIA BRASIL INDUSTRIAL, 1895)

A passagem retirada do relatório de 1895 parece demarcar um processo histórico que se constitui ao longo desses quase 20 anos nas relações de trabalho ali estabelecidas. Se na primeira citação a banda de música aparece sem nenhuma ênfase e quase despercebida em relação à escola, ela ainda se constitui como uma iniciativa dos próprios funcionários, apesar de ter que passar pelo consentimento da fábrica. A última passagem possui um tópico exclusivo para falar sobre essa mesma banda, que, no entanto, nesse momento, fora reorganizada pela direção da fábrica que "deu-lhes" um mestre.

Inicialmente, no trecho destacado os diretores demonstram aos seus acionistas que a experiência os levou a perceber a necessidade do ensino de música, já que os operários do estabelecimento "mostram gosto por tal arte.". A necessidade da banda de música que se referem os diretores parece vir do entendimento da importância dada àquela atividade pelos operários. Nesse viés, poderíamos interpretar a ação dos dirigentes como o reforço da bondade da direção em relação aos operários, que seriam gratos aos senhores diretores 
da fábrica de tecidos por permitirem aquele capricho. $\mathrm{O}$ que, no entanto, o documento nos mostra é um movimento mais profundo expresso na relação da diretoria com a banda operária.

A ação dos diretores da Brasil Industrial diante da iniciativa operária de formação da banda de música é a reprodução clara da ideologia patriarcal que rege as relações entre senhores e escravos no Império brasileiro. A lógica desta relação não prevê um movimento autônomo da vontade de seus subalternos. Pelo contrário, "a vontade senhorial é inviolável", e seus "subordinados só podem se posicionar como dependentes em relação a essa vontade soberana" (CHALHOUB, 2003. p.47). A leitura paternalista não compreendia a vontade dos subalternos a menos que expressassem o desejo dos seus senhores. Diante dessa lógica, era negada a existência da banda de música, a não ser que passasse pela vontade e iniciativa dos próprios diretores. Daí o movimento de reorganização da diretoria fabril naquele espaço aberto pelo operariado da Brasil Industrial. Os dirigentes retomam a banda de música e a inserem dentro da lógica paternal mais profunda de controle e tutela. No trecho "A aplicação e gosto desse pessoal, auxiliado pela diretora" (COMPANHIA BRASIL INDUSTRIAL, 1895), os diretores demonstram a tutela em relação aos trabalhadores, que somente poderiam participar de uma atividade que fosse julgada por esses senhores como boa, inofensiva, e não atrapalhasse a ordem e a produtividade do trabalho. Uma vez, que a banda fora compreendida como uma atividade inocente ela se insere no aspecto dadivoso do paternalismo, pois seus tutores "lhes dão um mestre de reconhecida idoneidade", ou seja, um trabalhador que a partir dos valores de seus patrões é julgado por uma conduta que o qualifica para tal atividade.

30 A própria ideia de idoneidade é constituinte do ideal de trabalhador que se pretendia para a indústria nesse momento, e considerada como um dos atributos mais importantes. 0 simples fato da direção da fábrica atestar a idoneidade do substituto e afirmar ter sido isso um acerto, ressalta o movimento de controle e tutela em que estavam inseridas as relações de trabalho daquele complexo fabril, diante do qual os subalternos estavam sempre subjugados aos valores e juízos dos senhores fabris.

31 Foi durante os primeiros 20 anos de implementação da fábrica em Macacos que se consolidou o projeto da Companhia Brasil Industrial. Durante esse período tomaram forma as primeiras acomodações dos operários, as casas que foram "arrendadas por preços módicos" (JORNAL DO COMÉRCIO, 1895) para as famílias que ali se estabeleceram, momento em que foi criado o armazém, lugar de abastecimento daquele complexo industrial, a escola noturna para aprendizes, tanto meninos quanto meninas, e quando foi construída a capela da fábrica.

32 Ainda no primeiro relatório foi colocado o desejo de se construir uma Igreja, "em futuro talvez não remoto" (COMPANHIA BRASIL INDUSTRIAL, 1874), para facilitar o aluguel de terrenos e a vinda de pessoas para a fábrica. No Nono Relatório (COMPANHIA BRASIL INDUSTRIAL,1892), consta o valor gasto na construção da capela que teria ocorrido no ano anterior, 1881.

33 A escola noturna para os aprendizes foi implementada desde 1876, como colocado pelo Quarto Relatório da Companhia (COMPANHIA BRASIL INDUSTRIAL,1877), mesmo ano em que foi formada a primeira banda de música e o ano em que o médico da Companhia passou a residir na localidade. No relatório de 1882 é possível perceber a expansão da escola noturna, quando foram implementadas duas outras aulas destinadas aos menores, uma para meninas dirigida pela professora Dona Bernarda do Nascimento Azevedo, e 
outra para desenho linear, dada pelo "senhor Gerente Veiga" ( COMPANHIA BRASIL INDUSTRIAL, 1882).

No $22^{\circ}$ Relatório de 1895 , já sob a direção de Domenique Level, foi saudada a iniciativa do governo do Rio de Janeiro de criar no perímetro da fábrica duas escolas para o ensino dos menores de ambos os sexos, filhos do pessoal do dito estabelecimento e dos habitantes de Macacos.

É com viva satisfação que, aproveitamos esta oportunidade, vos comunicamos que o governo do Estado do Rio de Janeiro, resolveu criar no perímetro da fábrica duas escolas para o ensino dos menores de ambos os sexos filhos do pessoal do dito estabelecimento e dos habitantes de Macacos e de suas circunvizinhanças. Tão útil medida começou a vigorar desde 24 de março deste ano, prestando a Companhia para os trabalhos escolares, as mesmas casas de suas escolas noturnas que continuam a funcionar a expensas suas, com o crescido número de 133 alunos que dela se utilizam com assídua frequência sem perturbação de seus trabalhos, donde tiram proveito pecuniário em auxilio da família. (COMPANHIA BRASIL INDUSTRIAL, 1895. p.8)

A passagem parece significar, diante dos primeiros passos da República do Brasil, o reconhecimento e apoio do governo aos industriais da Brasil Industrial e sua inserção no projeto republicano nacional. Também nos parece significativa do projeto operário destinado aos menores desde o início da implementação da Companhia.

Destarte, na formação do complexo fábrica com vila operária, estão as construções da rede de amparo que caracterizavam as relações paternalistas, antes escravocratas, e agora adaptadas ao modelo fabril. A rede de amparo construída no complexo fábrica com vila operária controla todos os bens e os distribui como dádiva. As casas da vila, armazém, serviços sanitários e médico, assim como atividades ligadas ao entretenimento e lazer formam as teias pelas quais transbordam sobre esse mundo do trabalho pretendido como moderno, as heranças das formas de controle que passam pela tutela e doação características da ideologia patriarcal do século XIX.

O controle sob esses bens aparece em uma matéria sobre a "Exposição de 1895 da produção industrial de tecidos algodão" do jornal do comércio:

Nas terras da Companhia, a qual arrenda a operários e agricultores, tem diversas casas nas proximidades da fábrica dotadas, as casas, de água filtrada canalizada e esgoto.

Por meio do armazém devidamente sortido fornece aos operários gêneros de primeira qualidade, apenas $5 \%$ mais caros do que os preços de primeira mão da capital.

O serviço sanitário que é prestado com a redistribuição de 3,8 \% pagando o operário no máximo 38 mensais consta de hospital, Médico e botica.

A fábrica tem um lazarento no meio da floresta para o tratamento de moléstias contagiosas e uma elegante capela em uma eminência serve para os atos religiosos, havendo missa 2 vezes por mês. (JORNAL DO COMÉRCIO, 1895).

Nas palavras desse jornal as iniciativas de moradia, saneamento e serviço médico, são descritas como extremamente positivas, um benefício aos trabalhadores, num discurso que reproduz a lógica paternal da bondade e tutela senhorial, sem as quais, esses "desamparados da sorte" (A REFORMA, 1874) não poderiam ter melhor destino. Dentre os serviços destacados pelo Jornal do Comércio estavam o armazém no qual era cobrado apenas $5 \%$ mais caro que na capital, o serviço sanitário que incluía médico, do qual eram descontados 3,8\% nos salários, a capela, um lazarento para doenças contagiosas, além das boas casas dotadas de água filtrada canalizada e esgoto, que eram arrendadas por 
operários ou agricultores (A REFORMA, 1874). Todos esses misteres constituíam uma rede de amparo aos trabalhadores do complexo da Brasil Industrial que passam a ser usados como instrumentos que pretendem o controle e submissão desses operários.

Esses bens de serviço eram oferecidos aos trabalhadores como doações, mesmo sendo descontados de sua folha de salário, como indica o jornal, apesar de não ter sido possível identificar a quantia paga pelos trabalhadores. Ainda que fossem módicos os valores descontados do salário dos operários, como parece indicar o periódico, seu significado se insere na dádiva e bondade dos discursos filantropos da elite do século XIX que mascaram o próprio sistema paternalista que forma no complexo fabril. A partir do controle e distribuição desses bens aos seus subalternos os dirigentes da Brasil Industrial fortaleciam e ampliavam seu domínio sobre a vida dos trabalhadores livres os submetendo aos seus julgamentos e vontades.

\section{BIBLIOGRAFIA}

A Reforma. Rio de Janeiro, 9 de junho de 1874.

BHABHA, Homi. K. O Local da Cultura. Belo Horizonte: Editora UFMG, 1998.

CERTEAU, Michel de. "Relatos de espaço". In: A Invenção do Cotidiano: 1. Artes de Fazer, 15a. ed. Petrópolis, Rj: Vozes, 2008, pp. 199-217.

CHALHOUB, Sidney. Visões de liberdade: uma história das últimas décadas da escravidão na corte. São Paulo: Companhia das Letras, 1990.

. Machado de Assis, Historiador. São Paulo: Companhia das Letras, 2003.

CIAVATTA, Maria. (coord.); DUARTE, Elisa Tavares [et al.]. Memória e Temporalidades do

Trabalho e da Educação. Rio de Janeiro: Faperj, 2007.

COMPANHIA BRASIL INDUSTRIAL. Primeiro Relatório aos Acionistas: 30 de janeiro de 1874.

Terceiro Relatório aos Acionistas: 15 de março de 1876.

Quarto Relatório aos Acionistas: 4 de outubro de 1877.

Quinto relatório aos Acionistas: 14 de novembro de 1878.

9ํำ Relatório aos Acionistas: 6 de setembro de 1882.

18ํำ Relatório aos Acionistas: 5 de novembro de 1891.

22º . Relatório aos Acionistas: 3 de setembro de 1895.

24ํㅡㄹ Relatório aos Acionistas: 22 de setembro de 1897.

33ํㅡㄹ Relatório aos Acionistas: 19 de setembro de 1906.

52º Relatório aos Acionistas: 4 de março de 1925.

GIROLETTI, Domingos. Fábrica: Convento e Disciplina. Brasília: Editora UNB, 2002. 
HERSCHMANN, Micael; LERNER, Kátia. Lance de Sorte: futebol e o jogo do bicho na Belle Epoque carioca. Rio de Janeiro: Diadorim, 1993.

Jornal do Comércio. Rio de Janeiro, 4 de dezembro de 1895.

KELLER, Paulo Fernandes. Fábrica e Vila Operária: a vida cotidiana dos operários têxteis em Paracambi/RJ. Engenheiro Paulo de Frontin: Solon Ribeiro, 1997.

KOSELLECK, Reinhart. Futuro Passado. Contribuição à semântica dos tempos históricos. Rio de Janeiro: Contraponto, Editora PUC-RJ, 2006.

LARA, Ś́lvia H. Escravidão, Cidadania e História do Trabalho no Brasil. Projeto História. São Paulo. 16:25-38, fev.1998.

LEITE LOPES, José S. A Tecelagem dos Conflitos de Classe na "Cidade das Chaminés". São Paulo: Marco Zero; Brasília: Editora da UNB,1988.

LUGÃO, Ana; MATTOS, Hebe. Memórias do cativeiro: Família, trabalho e cidadania no pósabolição. Rio de Janeiro: Civilização Brasileira, 2005.

MAGALHÃES, Cristiane Maria. “A paisagem fabril-têxtil no município de Itabira: uma experiência industrial no espaço rural”. In: BORGES, Maria Elisa Linhares (org). Campo e Cidade na Modernidade Brasileira: literatura, vilas operárias, cultura alimentar, futebol, correspondência privada e cultura visual. Belo Horizonte: Argumentum, 2008. pp.219-245.

MATTOS, Ilmar Rohloff de. O Tempo Saquarema. A Formação do Estado Imperial. $4^{\mathrm{a}}$ ed. Rio de Janeiro: Access, 1994.

NATAL, Clélia R. N.; NATAL, Gilson. História de Paracambi 1800 a 1987. Rio de Janeiro: Guavira Editores, [1987?].

NEGRO, Antonio Luigi; GOMES, Flávio. “Além de senzalas e fábricas, uma história social do trabalho". IN: Tempo Social, revista de sociologia da USP, v. 18, n. 1, jun. 2006, pp. 217-240.

o Globo. Rio de Janeiro, 5 de abril de 1875. p.2

O Mequetrefe. Rio de Janeiro, 9 de junho de 1874.

Rio de Janeiro, 5 de abril de 1875.

O Município. Vassouras, 01/1908-12/1912.

O Pharol. Juiz de Fora, 7 de agosto de 1903.

REIS, João José; SILVA, Eduardo. Negociação e Conflito: A resistência negra no Brasil escravista. São Paulo: Companhia das letras, 1989.

SLENES, Robert. Na Senzala uma Flor: esperanças e recordações na formação da família escrava: Brasil Sudeste, século XIX. Rio de Janeiro: Nova Fronteira, 1999.

STEIN, Stanley. Grandeza e decadência do café no vale do Paraíba: com referência especial ao município de Vassouras. São Paulo: Editora Brasiliense, 1961.

. Origens e Evolução da Indústria Têxtil no Brasil, 1850/1950. Rio de Janeiro: Editora Campus, 1979.

Vassouras, um município brasileiro do café, 1850-1900. Rio de Janeiro: Nova Fronteira, 1990.

SUZIGAN, Wilson. Indústria Brasileira: origem e desenvolvimento. São Paulo: Brasiliense, 1986. 
THOMPSON, E. P. A formação da classe operária inglesa. Rio de Janeiro: Paz e Terra, 1987.

. Costumes em Comum. São Paulo: Companhia das Letras, 1998.

\section{NOTAS}

1. O projeto industrial da Cia Brasil Industrial é discutido no primeiro relatório aos acionistas de 1874, para mais informações Cf.( SUZIGAN,1986).

2. Para a construção de novos laços de solidariedade ver também, (LUGÃO e MATTOS, 2005.).

3. A fábrica Santa Luisa foi fundada em 1891 e posteriormente Maria Cândida em 1924. Cf. (KELLER, 1997).

4. Para a discussão sobre a decadência dos senhores e novos espaços de liberdade, Ver também, (SLENES, 1999).

\section{RESUMOS}

A Companhia Brasil Industrial iniciou o projeto de construção de uma nova fábrica de tecidos na Província do Rio de Janeiro na segunda metade do século XIX. Construída aos pés da Serra do Mar, na região denominada Vale Paraíba, a fábrica constituiu o maior projeto da indústria têxtil do Império brasileiro.

O processo de formação da Companhia Brasil Industrial reconfigurou a paisagem do local, na segunda metade do Século XIX. O complexo fabril nasceu como a maior fábrica de tecidos do Brasil, e ao redor dessa grande estrutura se constituiu o povoado de Macacos, posteriormente chamado de Paracambi. Nessa localidade, regulado por esse mundo do trabalho, desenvolveramse experiências singulares de homens, mulheres, e crianças de diferentes origens, hábitos e costumes.

No espaço localizado entre um mundo rural, construído em torno da cultura do café, e o novo modelo industrial proposto pela fábrica, estão os esforços de transformação do espaço de uma fazenda num pólo fabril industrial moderno, supostamente capaz de marcar o rumo da modernização pretendida para a economia brasileira. Através das lacunas e contradições de tal projeto, no entanto, busca-se compreender os laços de continuidade que ligavam este novo empreendimento à antiga ordem, em especial no que diz respeito às políticas de domínio por ele constituídas.

Em meio ao processo de emancipação da escravidão e de criação de novas configurações sociais, se dá o início do planejamento e empreendimento da Brasil Industrial. A partir da implementação da Companhia torna-se possível observar o processo de estabelecimento de novas práticas que mediaram as relações daquele "mundo do trabalho" nascente. As formas de controle que dão vida ao novo sistema conjugaram e reelaboraram elementos pertencentes à relação senhorial que caracterizou por séculos a escravidão no Brasil. O sistema que se estabeleceu no novo "mundo do trabalho" criado pela fábrica de tecidos de Paracambi carregou as heranças desse paternalismo senhorial e se situou em uma espécie de "entre-lugar", para utilizarmos a acepção de Hommi Bhabha (1998) - apropriada aqui para demarcar o lugar situado entre a perpetuação das formas definidas pela escravidão e a inauguração de um paternalismo de caráter fabril. 
The Companhia Brasil Industrial started the construction of a new fabric factory in the Province of Rio de Janeiro in the second half of the 19th century. Built at the foot of the Serra do Mar, in Vale Paraíba region, the factory was the largest textile industry project in the Brazilian Empire. The formation process of Companhia Brasil Industrial reconfigured the local landscape in the second half of the 19th century. The manufacturing complex was born as the largest fabric factory in Brazil, and around this great structure was created the village of Macacos, later called Paracambi. In this locality, regulated by this world of work, singular experiences of men, women, and children of different origins, habits and customs were developed.

In the space between a rural world, built around the coffee culture, and the new industrial model proposed by the factory, are the efforts of transforming the space of a farm into a modern industrial factory pole, supposedly capable of setting the course of the intended modernization for the Brazilian economy. Through the gaps and contradictions of such a project, however, it seeks to understand the ties of continuity that linked this new enterprise to the old order, especially with respect to the domain policies that it constituted.

During the process of emancipation of slavery and the creation of new social configurations, the planning and entrepreneurship of Brasil Industrial begins. From the implementation of the Company it is possible to observe the process of establishing new practices that mediated the relationships of that nascent "working world". The forms of control that give life to the new system conjugated and reworked elements belonging to the seigniorial relation that characterized for centuries the slavery in Brazil. The system that established itself in the new "world of work" created by the Paracambi tissue factory carried the legacies of this manorial paternalism and placed itself in a sort of "in-between", to use the proper sense of Hommi Bhabha (1998) here to demarcate the place between the perpetuation of the forms defined by slavery and the inauguration of a paternalism of a factory character.

La Compañía Brasil Industrial inició el proyecto de construcción de una nueva fábrica de tejidos en la Provincia de Río de Janeiro en la segunda mitad del siglo XIX. Construida a los pies de la Sierra del Mar, en la región denominada "Vale Paraíba", la fábrica constituyó el mayor proyecto de la industria textil del Imperio brasileño.

El proceso de formación de la Compañía Brasil Industrial reconfiguró el paisaje del local, en la segunda mitad del siglo XIX. El complejo fabril nació como la mayor fábrica de tejidos de Brasil, y alrededor de esa gran estructura se constituyó el poblado de Macacos, posteriormente llamado de Paracambi. En esa localidad, regulado por ese mundo del trabajo, se desarrollaron experiencias singulares de hombres, mujeres, y niños de diferentes orígenes, hábitos y costumbres.

En el espacio situado entre un mundo rural, construido en torno a la cultura del café, y el nuevo modelo industrial propuesto por la fábrica, están los esfuerzos de transformación del espacio de una hacienda en un polo industrial moderno, supuestamente capaz de marcar el rumbo de la modernización pretendida para la economía brasileña. A través de las lagunas y contradicciones de tal proyecto, sin embargo, se busca comprender los lazos de continuidad que vinculaban este nuevo emprendimiento al antiguo orden, en especial en lo que se refiere a las políticas de dominio por él constituidas.

En medio del proceso de emancipación de la esclavitud y de creación de nuevas configuraciones sociales, se da el inicio de la planificación y emprendimiento de Brasil Industrial. A partir de la implementación de la Compañía se hace posible observar el proceso de establecimiento de nuevas prácticas que mediaron las relaciones del "mundo del trabajo" naciente. Las formas de control que dan vida al nuevo sistema conjugaron y reelaboraron elementos pertenecientes a la relación señorial que caracterizó por siglos la esclavitud en Brasil. El sistema que se estableció en el nuevo "mundo del trabajo" creado por la fábrica de tejidos de la ciudad Paracambi cargó las herencias de ese paternalismo señorial y se situó en una especie de "entre-lugar", para utilizar la acepción de Hommi Bhabha (1998) - apropiada aquí para demarcar el lugar situado entre la 
perpetuación de las formas definidas por la esclavitud y la inauguración de un paternalismo de carácter fabril.

La Compagnie Brasil Industrial a commencé la construction d'une nouvelle fabrique de tissus dans la province de Rio de Janeiro dans la seconde moitié du XIXe siècle. Construite au pied de la Serra do Mar, dans la région de la Valée Paraíba, l'usine était le plus grand projet de l'industrie textile de l'Empire brésilien.

Le processus de formation de la Compagnie Brasil Industrial a reconfiguré le paysage local dans la seconde moitié du 19ème siècle. Le complexe d'usine est né comme la plus grande usine de tissu au Brésil, et autour de cette grande structure a été créé le village de Macacos, appelé plus tard Paracambi. Dans cette localité, régulée par ce monde du travail, se sont développées des expériences singulières d'hommes, de femmes et d'enfants d'origines, d'habitudes et de coutumes différentes.

Dans l'espace situé entre un monde rural, construit autour de la culture du café, et le nouveau modèle industriel proposé par l'usine, se placent les efforts de transformer l'espace d'une ferme en un pôle industriel moderne, censé d'être capable de marquer le cours de la modernisation attendue pour l'économie brésilienne. A travers les lacunes et les contradictions d'un tel projet, cependant, on cherche à comprendre les liens de continuité qui liaient cette nouvelle entreprise à l'ancien ordre, notamment au regard des politiques de domaine constituées par elle.

$\mathrm{Au}$ milieu du processus d'émancipation de l'esclavage et de la création de nouvelles configurations sociales, a lieu le début de la planification et l'entreprenariat de la Compagnie Brasil Industrial .

A partir de la mise en œuvre de la Compagnie, il est possible d'observer le processus d'établissement de nouvelles pratiques qui ont influencé les relations de ce «monde du travail» naissant. Les formes de contrôle qui donnent vie au nouveau système ont conjugué et retravaillé des éléments appartenant à la relation seigneuriale qui a caractérisé pendant des siècles l'esclavage au Brésil. Le système qui s'est imposé dans le nouveau «monde du travail» créé par l'usine de tissus de Paracambi a hérité ce paternalisme seigneurial et s'est placé dans une sorte d '«inter-lieu», selon l'aception de Hommi Bhabha (1998), utilisée ici pour délimiter la place entre la perpétuation des formes définies par l'esclavage et l'inauguration d'un paternalisme de caractère d'usine.

\section{ÍNDICE}

Mots-clés: Monde du travail, Post-abolition, Valée Paraíba, Histoire économique, Industrie Fluminense.

Palabras claves: Mundo del trabajo, Post-abolición, Vale Paraíba, Historia Económica, Industria del Estado del Rio de Janeiro

Palavras-chave: Mundo do trabalho, Pós-abolição, Vale Paraíba, História Econômica, Indústria Fluminense.

Keywords: World of work, Post-abolition, Vale Paraíba, Economic History, Industry Fluminense.

\section{AUTOR}

\section{CRISTIANE SILVA FURTADO}

Mestra em História Social da Cultura pela PUC-Rio (2012), Doutoranda em História Social da Cultura pela PUC-Rio. Crissfurtado@gmail.com 